\title{
Characteristics of mushroom Phellinus baumii extracts with enzyme pretreatment
}

\author{
Eun Ji Son ${ }^{1}$ Eun-Ah Ryu ${ }^{1}$ Sang-Han Lee ${ }^{1,2} \cdot$ Young-Chan Kim ${ }^{3}$. \\ In-Wook Hwang ${ }^{4} \cdot$ Shin-Kyo Chung ${ }^{1,2}$ iD
}

\section{효소 전처리에 의한 상황버섯 $\beta$-glucan 추출물의 특성}

\author{
손은지 $^{1}$ - 류은아 ${ }^{1}$ - 이상한 ${ }^{1,2}$ - 김영찬 ${ }^{3}$ - 황인욱 ${ }^{4} \cdot$ 정신교 $^{1,2}$
}

Received: 1 February 2018 / Accepted: 19 March 2018 / Published Online: 31 March 2018

(C) The Korean Society for Applied Biological Chemistry 2018

\begin{abstract}
This study was conducted to establish optimized $\beta$ glucan extraction method through enzymatic hydrolysis from Phellinus baumii and investigate $\beta$-glucan contents and physicochemical properties. The optimal condition was obtained with the enzyme concentration of $0.66 \%(\mathrm{v} / \mathrm{v})$, reaction time of $6.08 \mathrm{~h}$ $\left(\mathrm{R}^{2}=0.9245\right)$ and the $\beta$-glucan contents from the Phellinus baumii extracts under the optimized condition was $1.9594 \mathrm{~g} / 100 \mathrm{~g}$. $\beta$ Glucan yield (0.76-16.40\%) of enzyme beta-glucan extract (EBE) was three fold higher than that of non-enzyme beta-glucan extract (NEBE). $\beta$-Glucan purity (11.15-59.05\%) of non-enzyme betaglucan (NEB) and that of enzyme beta-glucan (EB) were higher than that of NEBE and that of EBE. $\beta$-Glucan purity of EB $(59.05 \%)$ and $\beta$-glucan contents of EB (3.38 g/100 g) showed higher than those of others. Total sugar contents $(0.61-1.17 \mathrm{mg} /$
\end{abstract}

Shin-Kyo Chung $(\bowtie)$

E-mail: kchung@knu.ac.kr

${ }^{1}$ School of Food Science and Biotechnology, Kyungpook National University, Daegu 41566, Republic of Korea

${ }^{2}$ Food and Bio-industry Research Institute, Kyungpook National University, Daegu 41566, Republic of Korea

${ }^{3}$ SME Solution Center, Korea Food Research Institute, Jeollabuk-do 55365 , Republic of Korea

${ }^{4}$ Department of Food Science and Nutrition, Dong-A University, Busan 49315, Republic of Korea

This is an Open Access article distributed under the terms of the Creative Commons Attribution Non-Commercial License (http://creativecommons. org/licenses/by-nc/3.0/) which permits unrestricted non-commercial use, distribution, and reproduction in any medium, provided the original work is properly cited.
$\mathrm{mL}$ ) showed that NEB and EB were higher than that of NEBE and EBE, EB had the highest total sugar content as $1.17 \mathrm{mg} / \mathrm{mL}$, respectively. Protein contents $(0.44-11.73 \mathrm{mg} / \mathrm{mL})$ of NEBE and that of EBE were higher than that of NEB, that of EB. In FT-IR spectrum, the band at $890 \mathrm{~cm}^{-1}$ of microcapsule was attributed to a $\beta$-1,3-glucan. The toxicities of $\beta$-glucan from Phellinus baumii in both melanoma cell lines was determined using 3-(4,5dimethylthiazol-2-yl)-2,5-diphenyltetrazoli um bromide assay and $\beta$-glucan from Phellinus baumii has no toxicity until $30 \mu \mathrm{g} / \mathrm{mL}$. The effects of $\beta$-glucan from Phellinus baumii on inhibition of cancer cell proliferation were detected by using a wound healing assay. The effect of NEB and EB were higher than NEBE and EBE, especially $30 \mu \mathrm{g} / \mathrm{mL}$ of $\mathrm{EB}$ had the highest in both melanoma cell lines.

Keywords $\beta$-glucan · 3-(4,5-dimethylthiazol-2-yl)-2,5-diphenyltetrazoli um bromide assay $\cdot$ Enzymatic hydrolysis pretreatment $\cdot$ Phellinus baumii $\cdot$ Wound healing assay

\section{서 론}

상황버섯은 뽕나무 줄기 등에 자생하는 진흙버섯속의 백색 부 후균으로, 갓 표면을 제외한 모든 부분에서 황색을 띠어 상황 이라 불린다(Shin 등, 2008). 상황버섯은 전 세계적으로 약 220 여종이 존재하는 것으로 알려져 있으며, 국내에서는 Phellinus baumii, Phellinus linteus가 주로 재배 및 유통되고 있다(Bae 등, 2003). 최근 대량재배가 가능해지고, 암세포 증식 억제 활 성(Rhee 등, 2000), 면역 증강(Maja 등, 2011) 및 항산화 효과 
(Kim 등, 2011) 등의 다양한 생리활성이 보고되어 건강식품 및 의약품의 소재로 주목받고 있다. 이와 같은 상황버섯의 약리 기 능 중 항암 활성, 면역 증강 및 항염증 작용은 $\beta(1 \rightarrow 3)$ 주결합 에 $\beta(1 \rightarrow 6)$ 결합의 곁가지를 갖는 $\beta$-glucan에 의한 것이다 (Shiao 등, 1994). $\beta$-Glucan은 비특이적 면역반응으로 인간의 정 상 세포의 면역 기능을 활성화 시켜 암세포의 증식과 재발을 억제하고 혈당강하 및 혈중 콜레스테롤 감소 효과가 우수하며, 지질대사를 개선하여 체지방의 축적을 억제함으로써 항 비만효 과를 가지고 있는 것으로 보고되고 있다(Cho 등, 2013).

약용버섯류의 활용에 있어 가장 기본적인 처리공정은 재료로 부터 우수한 기능성과 생리활성을 가진 유효 성분을 분리하는 추출공정이다(Kim 등, 2007). 그러나 기존의 열수 추출 방법의 경우 추출 시간이 길고 추출 효율이 낮은 단점이 있어 이를 기 본으로 하며 유효 성분을 효과적으로 분리해낼 수 있는 적절한 전처리 기술이 필요하다(Kim 등, 2007). 약용버섯의 기능성 증 대를 위해 원적외선 처리(Kim 등, 2007), 초음파 처리(Kim 등, 2012), 가열 전처리(Park과 Kim 2008) 등에 대한 연구는 진행 되어 왔으나, 이러한 전처리 기술들은 적합한 장비가 요구되고, 저수율과 불안정성 때문에 상업적 사용이 제한된다(Chung과 Youn 2005). 이에 비하여, 효소 처리는 간편하며, 추출 수율이 높은데도 불구하고(Lee 등, 2014) 비교적 연구가 부족한 실정 이다. 본 연구에서는 상황버섯 $\beta$-glucan의 추출 효율을 높이기 위한 전처리 공정으로 효소 가수분해를 이용하였으며, 반응표면 분석법을 통해 효소 가수분해 조건을 최적화하였다. 최적화된 조건으로 효소 가수분해한 추출물을 열수 추출한 후 에탄올로 정제해 효율적인 추출 공정을 확립하였다. 이후 추출물의 $\beta$ glucan 함량 및 암세포 증식 억제 활성을 기존의 단순한 열수 추출 방법과 비교하여 조사하였다.

\section{재료 및 방법}

\section{실험재료}

본 실험에 사용한 상황버섯(Phellinus baumii)은 경상북도 안동 시 임하면 류충현 약용버섯에서 2016년 6월에 공여받은 2년산 상황버섯을 사용하였다. 2년산 상황버섯을 절단한 후 분쇄하여 25 mesh 이상의 상황버섯 분말을 제조하였다.

\section{반웅표면분석에 의한 효소 전처리 조건 최적화}

상황버섯 $\beta$-glucan 추출 조건의 최적화를 위하여 viscozyme의 첨가량 $\left(\mathrm{X}_{1}, \%(\mathrm{v} / \mathrm{v})\right)$ 과 반응 시간 $\left(\mathrm{X}_{2}, \mathrm{~h}\right)$ 을 독립 변수(independent variable)로 하여 실시하였다. 반응표면분석법 중 중심합성계획 법(central composite design)을 이용하였으며, 실험 범위에 따라 부호화된 독립변수와 부호화되지 않은 독립변수는 Table 1과 같 다. 추출 조건과 순서는 임의의 10 구간으로 정하여 진행하였다
(Kwon 등, 2003). 최적화하려는 $\beta$-glucan 함량을 종속 변수 (dependent variable, $\mathrm{Y}_{\mathrm{i}}$ )로 하였고, 독립변수와 종속변수간의 관 계를 조사하였다. 상황버섯의 viscozyme을 이용한 추출 조건에 따른 $\beta$-glucan의 특성은 statistical analysis system (SAS, version 9.4, SAS Institute Inc., Cary, NC, USA)을 이용하여 반응표면 회귀분석으로 통계 처리하였다. 또한, SAS program을 통하여 예측된 최적 추출 조건을 바탕으로 실증 시험하여 예측된 최적 값에 대한 백분율 $(\%)$ 로 나타내었다.

\section{상황버섯 $\beta$-glucan 추출 및 정제}

상황버섯 활성 다당체의 추출 공정은 Fig. 1과 같다. 상황버섯 분말 $50 \mathrm{~g}$ 과 증류수 $1 \mathrm{~L}(\mathrm{pH}$ 4)를 혼합한 후 $0.66 \%(\mathrm{v} / \mathrm{v})$ 의 viscozyme을 첨가하고 진탕배양기를 이용하여 $50{ }^{\circ} \mathrm{C}$, 회전속도 $130 \mathrm{rpm}$ 의 조건에서 6.08 시간 동안 반응시킨 후 24 시간 동안 $90{ }^{\circ} \mathrm{C}$ 에서 환류 추출하였으며(enzyme beta-glucan extract, $\mathrm{EBE})$, 여기에 $1 \mathrm{~L}$ 의 에탄올을 가해 $4{ }^{\circ} \mathrm{C}$ 에서 6 시간 방치하고 1 $\mathrm{L}$ 의 에탄올을 다시 한 번 가하여 24시간 방치한 후 여과하였 다. 여과액에 $1 \mathrm{~L}$ 의 에탄올을 가하여 24 시간 방치한 후 $1 / 4$ 로 농축하고 원심분리하여 정제하였다(enzyme beta-glucan, EB). 대 조구로 상황버섯 분말과 추출 용매인 증류수의 비를 $1: 20$ 으로 하여 24시간 동안 $90{ }^{\circ} \mathrm{C}$ 에서 환류 추출하고(non-enzyme betaglucan extract, NEBE), 이를 약 3 배량의 에탄올로 24 시간 동안 정제하였다(non-enzyme beta-glucan, NEB). 각 시료는 동결건조 하여 실험에 사용하였다.

\section{$\beta$-glucan 함량 측정}

추출 수율은 각 공정을 거쳐 추출한 상황버섯 추출물을 여과, 농축, 동결건조 한 후 무게를 측정하여 계산하였다. 수율은 건 조된 추출 물질이 상황버섯의 무게 중에서 차지하는 비율(\%)로 나타내었다.

$\beta$-glucan 함량은 Mushroom and Yeast $\beta$-glucan assay kit (Megazyme, Wicklow, Ireland)를 이용하여 측정하였다. $20 \mathrm{mg}$ 의 시료에 $12 \mathrm{M}$ sulphuric acid $2 \mathrm{~mL}$ 를 가하여 섞은 후 icewater bath에서 2 시간 동안 교반하며 반응시켰다. 이후 증류수 $10 \mathrm{~mL}$ 를 가하고 $100{ }^{\circ} \mathrm{C}$ 에서 2 시간 동안 반응시킨 반응액을 식 힌 후 $10 \mathrm{M}$ potassium hydroxide $6 \mathrm{~mL}$ 를 가하였다. 이후 200 $\mathrm{mM}$ sodium acetate buffer $(\mathrm{pH}$ 5.0)로 $100 \mathrm{~mL}$ 로 정용하였다. Whatman GF/A glass microfiber filter (GE Healthcare, Amersham, $\mathrm{UK}$ )를 이용해 여과하고, 여과액 $0.1 \mathrm{~mL}$ 에 exo-1,3- $\beta$-glucanase $(20 \mathrm{U} / \mathrm{mL})+\beta$-glucosidase $(4 \mathrm{U} / \mathrm{mL}) \quad 0.1 \mathrm{~mL}$ 를 혼합하였다. 40 ${ }^{\circ} \mathrm{C}$ water bath에서 1시간 동안 반응시킨 후 반응액에 glucose oxidase/peroxidase mixture (GOPOD) $3 \mathrm{~mL}$ 를 가해 $40^{\circ} \mathrm{C}$ 에서 20 분간 반응시켰다. 이후 UV-visible Spectrometer (UV 1601, Shimadzu, Kyoto, Japan)을 이용해 $510 \mathrm{~nm}$ 에서 흡광도를 측정 하여 total glucan 함량을 측정하였다. 또한 $20 \mathrm{mg}$ 의 시료에 2

Table 1 Coded level for independent variables used in developing data for preparation of glucan extraction from Phellinus baumii

\begin{tabular}{lccccccc}
\hline \hline \multirow{2}{*}{ Independent variable } & \multirow{2}{*}{ Units } & Coded & \multicolumn{5}{c}{ Coded levels } \\
\cline { 4 - 8 } & & $\mathrm{Xi}$ & -2 & -1 & 0 & 1 & 2 \\
\hline Enzyme concentration & $\%(\mathrm{v} / \mathrm{v})$ & $\mathrm{X}_{1}$ & 0.2 & 0.4 & 0.6 & 0.8 & 1.0 \\
Enzyme reaction time & hours & $\mathrm{X}_{2}$ & 2 & 4 & 6 & 8 & 10 \\
\hline
\end{tabular}




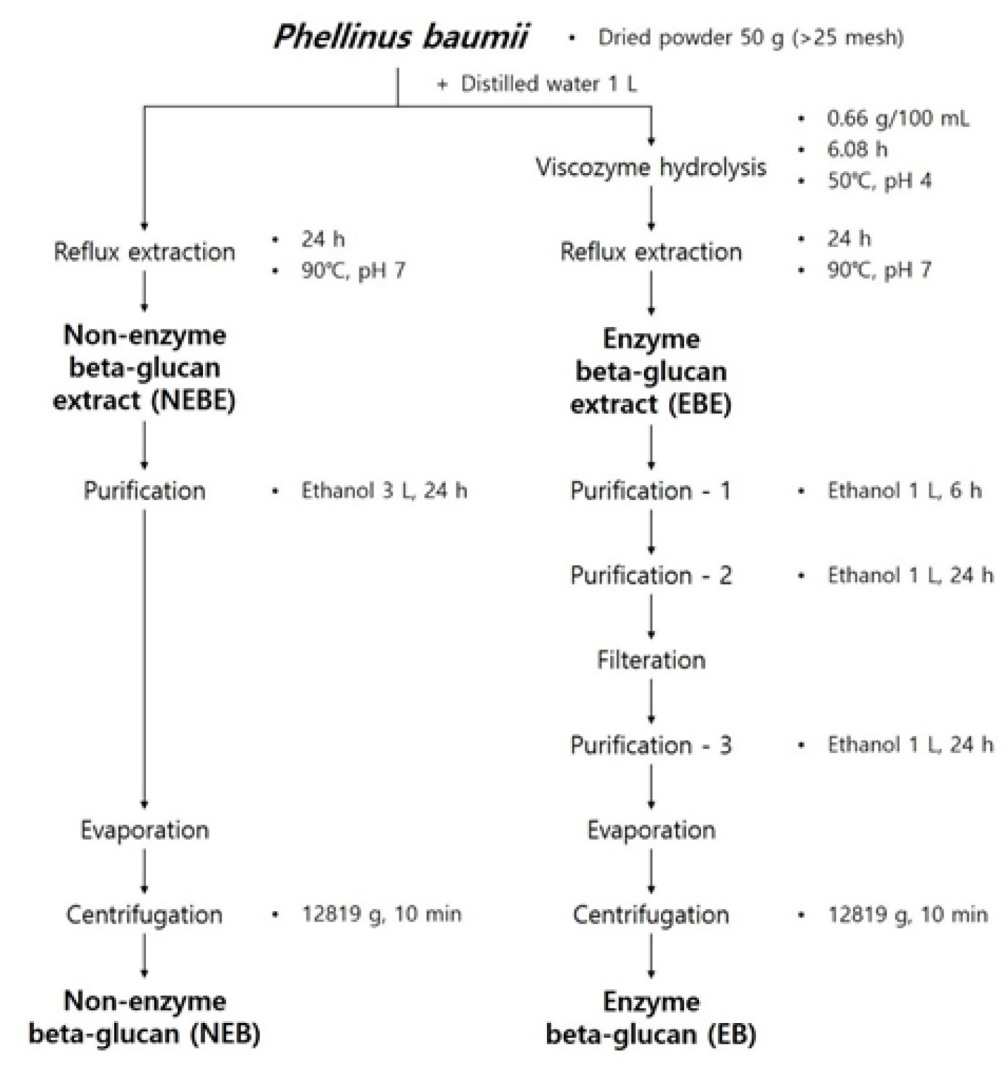

Fig. 1 Scheme of $\beta$-glucan extraction from Phellinus baumii.

M potassium hydroxide $2 \mathrm{~mL}$ 를 가하여 20 분 동안 ice-water bath에서 반응시켰다. 이후 $1.2 \mathrm{M}$ sodium acetate buffer $(\mathrm{pH}$ 3.8) $8 \mathrm{~mL}$ 와 amyloglucosidase $(1630 \mathrm{U} / \mathrm{mL})+$ invertase $(500 \mathrm{U} /$ $\mathrm{mL}) 0.2 \mathrm{~mL}$ 를 가하여 $40{ }^{\circ} \mathrm{C}$ 에서 30 분 동안 반응시켰다. 반응액 을 $1500 \mathrm{~g}$ 로 10 분간 원심분리 후 상등액 $0.1 \mathrm{~mL}$ 에 $200 \mathrm{mM}$ sodium acetate buffer (pH 5.0) $0.1 \mathrm{~mL}$ 와 GOPOD $3 \mathrm{~mL}$ 를 가해 $40{ }^{\circ} \mathrm{C}$ 에서 20 분간 반응시켰다. 이후 $510 \mathrm{~nm}$ 에서 흡광도를 측정하여 $\alpha$-glucan 함량을 측정하였다. $\beta$-Glucan 함량은 total glucan 함량에서 $\alpha$-glucan 함량을 제외한 값으로 하여 계산하였다.

\section{총당 및 단백질 함량 측정}

총당 함량은 페놀-황산법으로 측정하였다(Dubois 등, 1956). 시 료 $1 \mathrm{~g}$ 에 $5 \%$ phenol $1 \mathrm{~mL}$ 와 $95 \%$ sulfuric acid $5 \mathrm{~mL}$ 를 가하 여 30 분간 상온에서 반응시킨 후 $470 \mathrm{~nm}$ 에서 흡광도를 측정하 였다. 결과는 표준물질 glucose 검량선의 회귀식을 이용하여 $\mathrm{mg}$ / $\mathrm{mL}$ 로 환산하여 나타내었다.

단백질 함량은 bicinchoninic acid (BCA) assay를 이용하여 측정하였다(Smith 등, 1985). 시료의 조추출물 $(1 \mathrm{mg} / \mathrm{mL}) 10 \mu \mathrm{L}$ 에 BCA solution (Cooper II sulfate : bicinchoninic acid= $1: 50) 90 \mu \mathrm{L}$ 를 가해 $37^{\circ} \mathrm{C}$ 에서 30 분간 반응시킨 후 $595 \mathrm{~nm}$ 에 서 흡광도를 측정하였다. 결과는 표준물질 bovine serum albumin 검량선의 회귀식을 이용하여 $\mathrm{mg} / \mathrm{mL}$ 로 환산하여 나타 내었다.

\section{구성당 분석}

구성당 분석은 Prominence Modular HPLC system (Shimadzu Co.)를 이용하여 측정하였다. 구성당 분석을 위하여 시료 $10 \mathrm{mg}$ 을 $6 \mathrm{~N}$ hydrochloric acid로 가수분해한 후 증발건조하였다. 이 를 증류수에 용해시켜 $0.45 \mu \mathrm{m}$ membrane filter (DISMIC-25HP, Advantec Co., Ltd., Tokyo, Japan)로 여과하였다. Sugar-Pak I column $(10 \mu \mathrm{m}, \varnothing 6.5 \times 300 \mathrm{~mm}$, Waters Corporation, Milford, CT, USA)을 사용하여 $0.01 \mathrm{M}$ Ca-EDTA buffer를 이동상으로 하여 $0.5 \mathrm{~mL} / \mathrm{min}$ 으로 RI detector로 분석하였다.

\section{FT-IR 분석}

$\beta$-Glucan의 작용기를 확인하기 위해서 FT-Infrared spectrophotometer (FT-IR, Frontier, PerkinElmer, MA, USA)을 이용하여 spectrum을 분석하였다.

\section{Cell culture}

암세포주 B16F10 murine melanoma cell과 SK-MEL-5 human melanoma cell은 한국세포주은행에서 분양받았다. $10 \%$ fetal bovine serum, $14 \%$ antibiotic (100 unit $/ \mathrm{mL}$ penicillin, $100 \mu \mathrm{g} /$ $\mathrm{mL}$ streptomycin)를 첨가한 Dulbeco's Modified Eagle's Medium 과 Roswell Park Memorial Institute Medium (RPMI-1640)를 이용하여 $5 \% \mathrm{CO}_{2}$ 및 $37{ }^{\circ} \mathrm{C}$ 의 조건에서 배양하였다. 


\section{세포 독성}

세포 독성을 알아보기 위해 B16F10 murine melanoma cell과 SK-MEL-5 human melanoma cell을 이용하여3-(4,5-dimethylthiazol-2-yl)-2,5-diphenyltetrazoli um bromide (MTT) assay를 실시하였다(Mossmann 1983). B16F10 murine melanoma cell 과 SK-MEL-5 human melanoma cell을 96 well plate에 5.0× $10^{4} \mathrm{cell} / \mathrm{mL}$ 로 분주한 후 부착 및 안정화를 위하여 $37^{\circ} \mathrm{C}$ 의 $\mathrm{CO}_{2}$ incubator에서 24시간 동안 배양하였다. 시료의 농도는 100 $\mu \mathrm{g} / \mathrm{mL}$ 로부터 희석하였고, 희석된 시료를 배양된 세포에 처리하 여 다시 24 시간 동안 배양하였다. 배양액을 제거한 후 $10 \%$ MTT (Thiazolylblue tetrazolium bromide) solution $(5 \mathrm{mg} / \mathrm{mL}$ in phosphate-bufferedsaline) $100 \mu \mathrm{L}$ 를 가하여 다시 1 시간 동안 배양하였다. 배양액을 제거하고, DMSO $100 \mu \mathrm{L}$ 를 가하여 생성 된 formazan을 용해시킨 후 multiable counter (Victor3 1420, PerkinElmer Inc.)를 이용하여 $590 \mathrm{~nm}$ 에서 흡광도를 측정하였다. 결과는 대조구와 비교하여 나타내었다.

\section{Wound healing assay}

세포의 운동성 억제효과를 확인하기 위한 in vitro wound healing assay를 실시하였다(Heo 등, 2005). B16F10 murine melanoma cell과 SK-MEL-5 human melanoma cell을 6 well plate에 $3 \times 10^{5}$ cells/well로 분주한 후 $37^{\circ} \mathrm{C}$ 의 $\mathrm{CO}_{2}$ incubator에서 24 시 간 동안 배양하였다. 이후 yellow pipette tip을 이용하여 cell의 표면에 wound를 형성시키고 배양액을 교체하였다. 시료를 3 , $10,30 \mu \mathrm{g} / \mathrm{mL}$ 의 농도로 처리하여 $37^{\circ} \mathrm{C}$ 의 $\mathrm{CO}_{2}$ incubator에서 배양하면서 $0,6,12$ 시간 간격으로 healing 정도를 현미경 (ECLIPSE TE2000-U, Nikon, Tokyo, Japan)으로 관찰하였다. Wound healing 비율은 wound의 거리를 측정하여 억제활성의 정도를 대조구와 비교하였다.

\section{통계 처리}

모든 실험은 3회 반복하여 결과값을 평균과 표준편차로 나타내 었고(mean $\pm \mathrm{SD})$, Statistical analysis system (SAS, version 9.4, SAS Institute Inc., Cary, NC, USA)에 의하여 유의차를 검정하였다(Duncan's multiple range test, $p<0.05$ ).

\section{결과 및 고찰}

\section{반웅표면분석에 의한 효소 전처리 조건 최적화}

상황버섯 $\beta$-glucan 추출조건의 최적화를 위해 반응표면분석을 실시하였으며, 그에 따라 종속변수인 $\beta$-glucan 함량을 측정한 결과는 Table 2 와 같다. 추출 조건 별 $\beta$-glucan 함량은 1.0093$2.0440 \mathrm{~g} / 100 \mathrm{~g}$ 의 범위로 나타났으며, $0.6 \mathrm{~g} / 100 \mathrm{~mL}$ 의 효소를 6
Table 2 Experimental order of central composite design used for response surface methodology with two independent variables for Phellinus baumii extraction

\begin{tabular}{cccc}
\hline \hline \multirow{2}{*}{ Standard order } & \multicolumn{2}{c}{ Independent variables } & $\begin{array}{c}\text { Response } \\
\text { variables }\end{array}$ \\
\cline { 2 - 4 } & $\begin{array}{c}\text { Enzyme } \\
\text { concentration } \\
\left(\mathrm{X}_{1}, \%(\mathrm{v} / \mathrm{v})\right)\end{array}$ & $\begin{array}{c}\text { Enzyme } \\
\text { reaction time } \\
\left(\mathrm{X}_{2}, \text { hours }\right)\end{array}$ & $\begin{array}{c}\beta \text {-glucan } \\
\text { contents } \\
(\mathrm{g} / 100 \mathrm{~g})\end{array}$ \\
\hline 1 & $0.8(1)$ & $8(1)$ & 1.6650 \\
2 & $0.8(1)$ & $4(-1)$ & 1.6065 \\
3 & $0.4(-1)$ & $8(1)$ & 1.5736 \\
4 & $0.4(-1)$ & $4(-1)$ & 1.5281 \\
5 & $0.6(0)$ & $6(0)$ & 1.9868 \\
6 & $0.6(0)$ & $6(0)$ & 2.0440 \\
7 & $1.0(2)$ & $6(0)$ & 1.5709 \\
8 & $0.2(-2)$ & $6(0)$ & 1.0093 \\
9 & $0.6(0)$ & $10(2)$ & 1.4832 \\
10 & $0.6(0)$ & $2(-2)$ & 1.4816 \\
\hline
\end{tabular}

Table $3 \beta$-Glucan contents of Phellinus baumii extracts at the optimal condition

\begin{tabular}{ccccc}
\hline \hline \multirow{2}{*}{ Variables } & \multicolumn{2}{c}{ Critical value } & \multicolumn{2}{c}{$\beta$-glucan $(\mathrm{g} / 100 \mathrm{~g})$} \\
\cline { 2 - 5 } & Coded & Uncoded & Predicted & Experimental \\
\hline $\mathrm{X}_{1}$ & 0.1553 & 0.6621 & \multirow{2}{*}{1.9708} & 1.9594 \\
$\mathrm{X}_{2}$ & 0.0198 & 6.0792 & & \\
\hline
\end{tabular}

시간 동안 반응시켰을 때 가장 높은 함량을 보였다.

각 실험 구간에서 최대 반응값을 가지기 위한 조건으로 viscozyme 농도는 되었으며 $\left(\mathrm{R}^{2}=0.9245\right)$, 이 조건에서의 $\beta$-glucan 함량은 $1.9708 \mathrm{~g} / 100 \mathrm{~g}$ 으로 예측되었다(Table 3). 이에 따라 최 적 추출 조건에서 추출한 시료의 $\beta$-glucan 함량은 $1.9594 \mathrm{~g} / 100$ $\mathrm{g}$ 으로 측정되었으며, 이는 예측된 $\beta$-glucan 함량 $(1.9708 \mathrm{~g} / 100 \mathrm{~g})$ 과 $99.42 \%$ 유사하였다.

\section{$\beta$-glucan 함량 측정}

각 시료의 추출 수율 및 $\beta$-glucan 함량은 Table 4와 같다. 수 율은 효소 전처리한 $\mathrm{EBE}(16.40 \%)$ 가 $\mathrm{NEBE}(5.20 \%)$ 보다 약 3 배 높았으며, $\mathrm{NEB}$ 가 $0.76 \%, \mathrm{~EB}$ 가 $5.72 \%$ 로 효소 전처리구와 대조구 모두 정제 과정을 거치며 수율은 크게 낮아졌다 $(p<0.05)$. $\beta$-glucan 순도는 NEBE (18.97 $\pm 0.47 \%)$ 가 $\mathrm{EBE}(11.15 \pm 0.04 \%)$ 보다 높았으나 $(p<0.05)$, 정제를 할 경우 $\mathrm{EB} \quad(59.05 \pm 0.63 \%)$ 가 $\mathrm{NEB}(26.64 \pm 0.27 \%)$ 에 비해 약 2.2 배 높았다. 순도와 수율을 함께 고려한 상황버섯 $100 \mathrm{~g}$ 당 $\beta$-glucan의 함량 $(\mathrm{g})$ 은 NEBE가 $0.99 \pm 0.03 \mathrm{~g} / 100 \mathrm{~g}, \mathrm{EBE}$ 가 $1.83 \pm 0.01 \mathrm{~g} / 100 \mathrm{~g}$ 으로 $\mathrm{EBE}$ 가 NEBE 에 비해 약 1.8 배 높았다. $\mathrm{EB}$ 의 경우 $3.38 \pm 0.04 \mathrm{~g} / 100 \mathrm{~g}$ 로 $0.26 \pm$

Table 4 Yield and $\beta$-glucan contents of Phellinus baumii extracts with enzyme treatment

\begin{tabular}{|c|c|c|c|c|}
\hline & $\mathrm{NEBE}^{1)}$ & NEB & $\mathrm{EBE}$ & EB \\
\hline Yield (\%) & $5.20 \pm 0.17^{\mathrm{c} 2)}$ & $0.76 \pm 0.10^{d}$ & $16.40 \pm 0.74^{\mathrm{a}}$ & $5.72 \pm 0.13^{b}$ \\
\hline$\beta$-glucan purity (\%) & $18.97 \pm 0.47^{\mathrm{c}}$ & $26.64 \pm 0.27^{b}$ & $11.15 \pm 0.04^{\mathrm{d}}$ & $59.05 \pm 0.63^{\mathrm{a}}$ \\
\hline$\beta$-glucan contents $(\mathrm{g} / 100 \mathrm{~g})$ & $0.99 \pm 0.03^{\mathrm{c}}$ & $0.26 \pm 0.01^{\mathrm{d}}$ & $1.83 \pm 0.01^{\mathrm{b}}$ & $3.38 \pm 0.04^{\mathrm{a}}$ \\
\hline
\end{tabular}

\footnotetext{
${ }^{1)}$ NEBE, non-enzyme beta-glucan extract; NEB, non-enzyme beta-glucan; EBE, enzyme beta-glucan extract; EB, enzyme beta-glucan
} ${ }^{2) a b c}$ Means followed by the same letters within the row are not significantly different $(p<0.05)$. Values are expressed as the mean ${ }^{\circ} \mathrm{S}$.D. 
Table 5 Total sugar and protein contents of the Phellinus baumii extracts with enzyme treatment

\begin{tabular}{llrr}
\hline \hline & NEBE & NEB & EBE \\
\hline Total sugar contents $(\mathrm{mg} / \mathrm{mL})$ & $0.66 \pm 0.01^{\mathrm{c} 2)}$ & $0.75 \pm 0.04^{\mathrm{b}}$ & $0.61 \pm 0.02^{\mathrm{d}}$ \\
Protein contents $(\mathrm{mg} / \mathrm{mL})$ & $5.02 \pm 0.26^{\mathrm{b}}$ & $0.44 \pm 0.05^{\mathrm{d}}$ & $1.17 \pm 0.03^{\mathrm{a}}$ \\
\hline
\end{tabular}

${ }^{15} \mathrm{NEBE}$, non-enzyme beta-glucan extract; NEB, non-enzyme beta-glucan; EBE, enzyme beta-glucan extract; EB, enzyme beta-glucan

${ }^{2) a b c}$ Means followed by the same letters within the row are not significantly different $(p<0.05)$. Values are expressed as the mean ${ }^{\circ}$ S.D.

Table 6 Sugar relative composition of the Phellinus baumii extracts with enzyme treatment

(Unit: \%)

\begin{tabular}{lccccc}
\hline \hline & Glucose & Galactose & Fructose & Arabinose & Mannitol \\
\hline NEBE $^{1)}$ & 84.03 & 10.52 & 0.01 & 0.96 & 4.42 \\
NEB & 87.13 & 10.70 & ND $^{2}$ & 2.09 & 0.01 \\
EBE & 51.90 & 45.62 & 0.23 & 0.20 & 2.05 \\
EB & 84.61 & 7.99 & 1.21 & ND & 1.66 \\
\hline
\end{tabular}

${ }^{1)} \mathrm{NEBE}$, non-enzyme beta-glucan extract; NEB, non-enzyme beta-glucan; EBE, enzyme beta-glucan extract; EB, enzyme beta-glucan

${ }^{2)} \mathrm{ND}$, not dectected

$0.01 \mathrm{~g} / 100 \mathrm{~g}$ 의 NEB보다 약 13 배 높았기에 함량이 크게 높아진 것을 확인할 수 있었다.

\section{총당 및 단백질 함량}

처리조건에 따른 상황버섯 추출물의 총당과 단백질 함량은 Table 5 와 같다. 총당 함량은 대조구와 효소 전처리구 모두 정제한 것 이 높았다. $\mathrm{NEB}(0.75 \pm 0.04 \mathrm{mg} / \mathrm{mL})$ 가 $\mathrm{NEBE}(0.66 \pm 0.01 \mathrm{mg} /$ $\mathrm{mL})$ 보다, $\mathrm{EB}(1.17 \pm 0.03 \mathrm{mg} / \mathrm{mL})$ 가 $\mathrm{EBE}(0.61 \pm 0.02 \mathrm{mg} / \mathrm{mL})$ 보 다 높았으며, $\mathrm{EB}$ 가 가장 높게 나타났다 $(p<0.05)$.

단백질 함량은 대조구에서 정제한 NEB $(0.44 \pm 0.05 \mathrm{mg} / \mathrm{mL})$ 가 $\mathrm{NEBE}(5.02 \pm 0.26 \mathrm{mg} / \mathrm{mL})$ 보다 약 11 배 낮았으며, 효소 전처리 구 역시 정제한 $\mathrm{EB}(0.78 \pm 0.02 \mathrm{mg} / \mathrm{mL})$ 가 $\mathrm{EBE}(11.73 \pm 0.95$ $\mathrm{mg} / \mathrm{mL})$ 보다 약 15 배 낮았다 $(p<0.05)$.

Suh 등(2002)은 viscozyme L이 식물세포벽성분과 단백질을 분해하는 효소로서 세포벽의 다당체를 분해한 후 단백질을 저 분자로 분해 제거하고 전분을 절단하는 효소 처리 과정을 거치 면서 저분자 유용성분이 극대화된다고 보고하였다.

\section{구성당 분석}

구성당 함량은 Table 6과 같으며 glucose와 galactose, mannitol 은 모든 시료에서 검출되었다. Glucose의 경우 대조구와 효소 처리구 모두 정제하지 않은 $\mathrm{NEBE}$ 와 $\mathrm{EBE}$ 보다 정제한 $\mathrm{NEB}$ 와 $\mathrm{EB}$ 의 구성 비율이 높았으므로 정제가 잘 이루어졌다고 판단하 였다. Fructose는 NEB에서, mannitol은 $\mathrm{EB}$ 에서 검출되지 않았다. 상황버섯에는 glucose, fructose, galactose, rhamnose, arabinose, mannose 등이 존재한다고 보고된 바 있다(Maja 등, 2011).

\section{FT-IR 분석}

FT-IR 분석 결과는 Fig. 2와 같다. 각 peak의 작용기는 3300$3400 \mathrm{~cm}^{-1}$ 영역에서 당 고리의 전형적인 $\mathrm{O}-\mathrm{H}$ 의 stretching peak 가 수소결합에 의해 이동되어 나타났으며, $\mathrm{EBE}$ 와 $\mathrm{EB}$ 에서 크게 나타났다. 모든 시료에서 $2900 \mathrm{~cm}^{-1}$ 부근의 C-H stretching 진 동과 $1630 \mathrm{~cm}^{-1}$ 의 $\mathrm{C}-\mathrm{O}$ stretching 진동, $1000-1100 \mathrm{~cm}^{-1}$ 에서는 $\mathrm{C}-\mathrm{H}$ 와 C-O bending 진동이 나타났다. Vlasta 등(2001)의 표고, 영지, 느타리버섯 등 약 70 여 종의 버섯에 대한 FT-IR 패턴 연

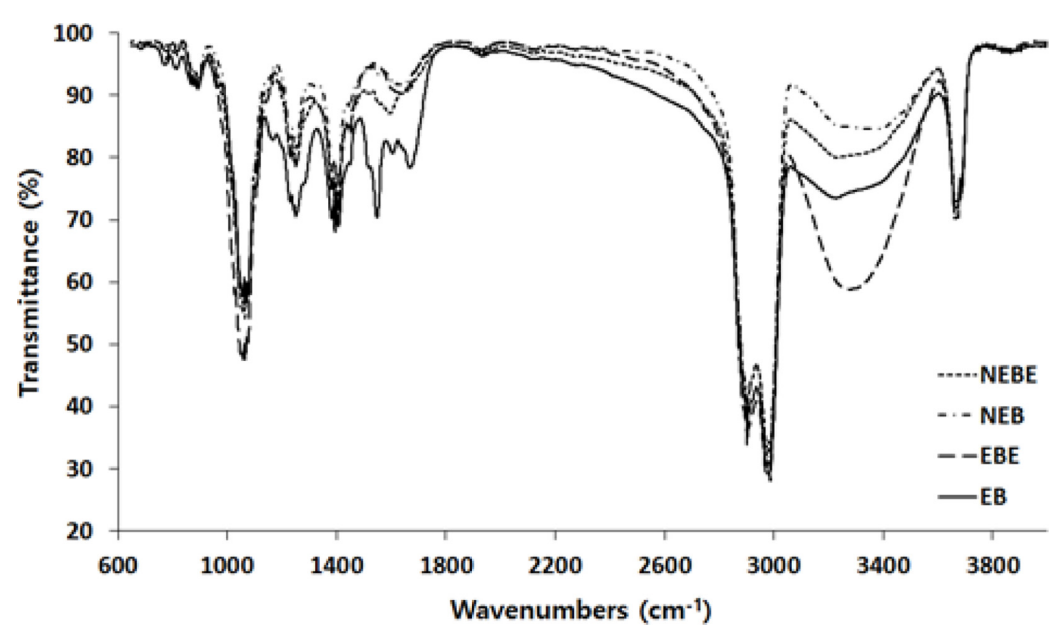

Fig. 2 FT-IR spectrum of Phellinus baumii extracts with enzyme pretreatment. NEBE, non-enzyme beta-glucan extract; NEB, non-enzyme beta-glucan; EBE, enzyme beta-glucan extract; EB, enzyme beta-glucan 


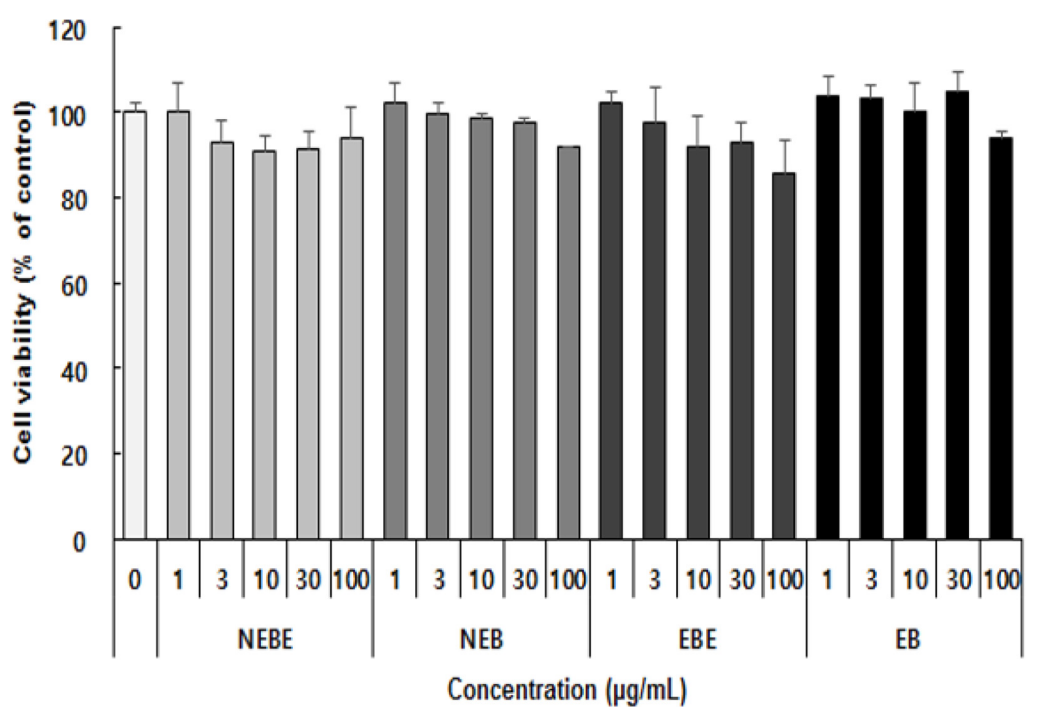

Fig. 3 Effect of the Phellinus baumii extracts with enzyme treatment on cell viability of B16F10. NEBE, non-enzyme beta-glucan extract; NEB, nonenzyme beta-glucan; EBE, enzyme beta-glucan extract; EB, enzyme beta-glucan

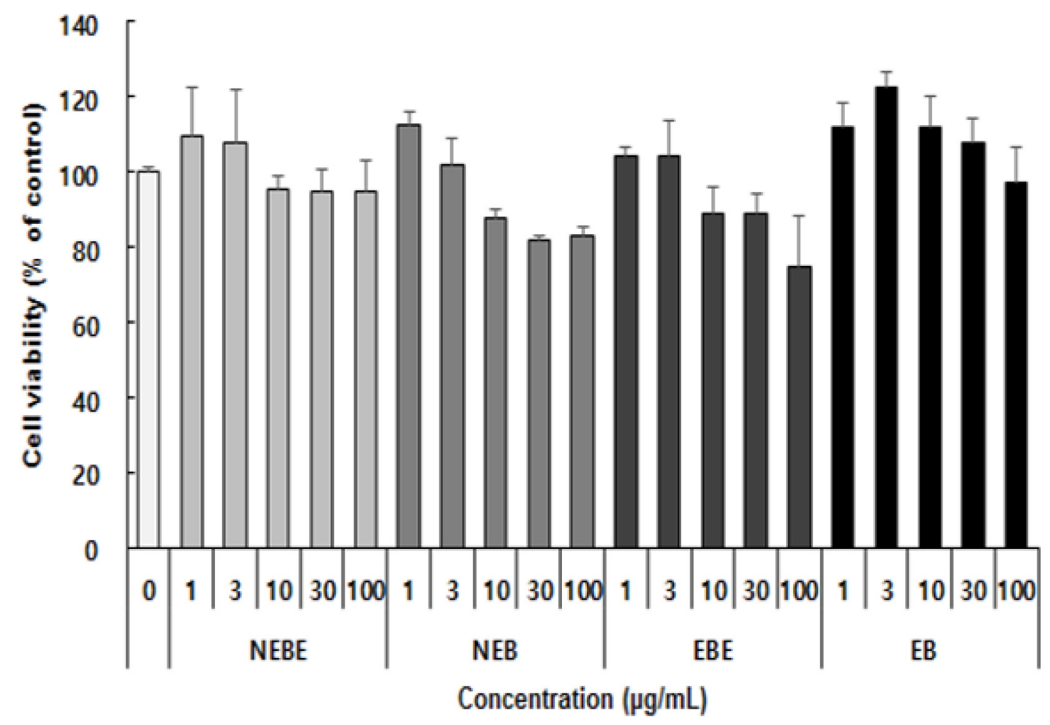

Fig. 4 Effect of the Phellinus baumii extracts with enzyme treatment on cell viability of SK-MEL-5. NEBE, non-enzyme beta-glucan extract; NEB, non-enzyme beta-glucan; EBE, enzyme beta-glucan extract; EB, enzyme beta-glucan

구에서 $890 \mathrm{~cm}^{-1}$ 영역은 $\beta$-glycosidic linkage를 나타내며, 930 $\mathrm{cm}^{-1}$ 영역은 $\alpha$-glycosidic linkage를 나타낸다고 보고된 바 있다. 본 연구의 추출물 역시 $890 \mathrm{~cm}^{-1}$ 부근에서 peak가 확인되었기 에 $\beta$-glycosidic linkage를 가지고 있는 것으로 판단하였다.

\section{세포 독성}

시료가 세포의 생존과 증식에 미치는 영향을 알아보기 위하여 MTT assay를 통해 B16F10과 SK-MEL-5에 대한 세포 독성을 측정한 결과는 Fig. 3,4 과 같다. 시료는 $1,3,10,30,100$ $\mu \mathrm{g} / \mathrm{mL}$ 의 농도로 처리하였다. $\mathrm{B} 16 \mathrm{~F} 10$ 의 경우 대조구의 세포 생 존율을 $100 \%$ 로 하였을 때 $1-100 \mu \mathrm{g} / \mathrm{mL}$ 의 농도에서 세포 생존 율이 $80 \%$ 이상으로 나타나 세포독성을 보이지 않았다. 반면 SK-MEL-5에서는 EBE를 $100 \mu \mathrm{g} / \mathrm{mL}$ 의 농도로 처리하였을 때
세포 생존율이 $75.09 \%$ 로 나타나 약간의 세포독성을 보였다. 치 마버섯균 유래 $\beta$-glucan 50, 100, 200, $400 \mu \mathrm{g} / \mathrm{mL}$ 를 Raw 264.7 세포에 처리한 Lee 등(2011)의 결과에서 저농도 $(50 \mu \mathrm{g} /$ $\mathrm{mL})$ 부터 고농도 $(400 \mu \mathrm{g} / \mathrm{mL})$ 까지 세포 독성이 나타나지 않았다.

\section{Wound healing assay}

암의 전이는 암세포의 특징으로 전이에서 가장 중요한 요소로 서 암세포의 운동성을 들 수 있다. 세포의 운동성은 세포의 형 태가 바뀌면서 일정한 방향성과 함께 관찰할 수 있다(Park 등, 2009). 따라서 상황버섯 추출물의 B16F10과 SK-MEL-5에 대한 암세포 증식 억제 활성을 알아보기 위하여 wound healing assay를 실시한 결과는 Fig. 5, 6과 같다. SK-MEL-5 cell에 wound를 형성한 후 $3 \mu \mathrm{g} / \mathrm{mL}$ 의 $\mathrm{EBE}$ 를 처리한 경우를 제외한 


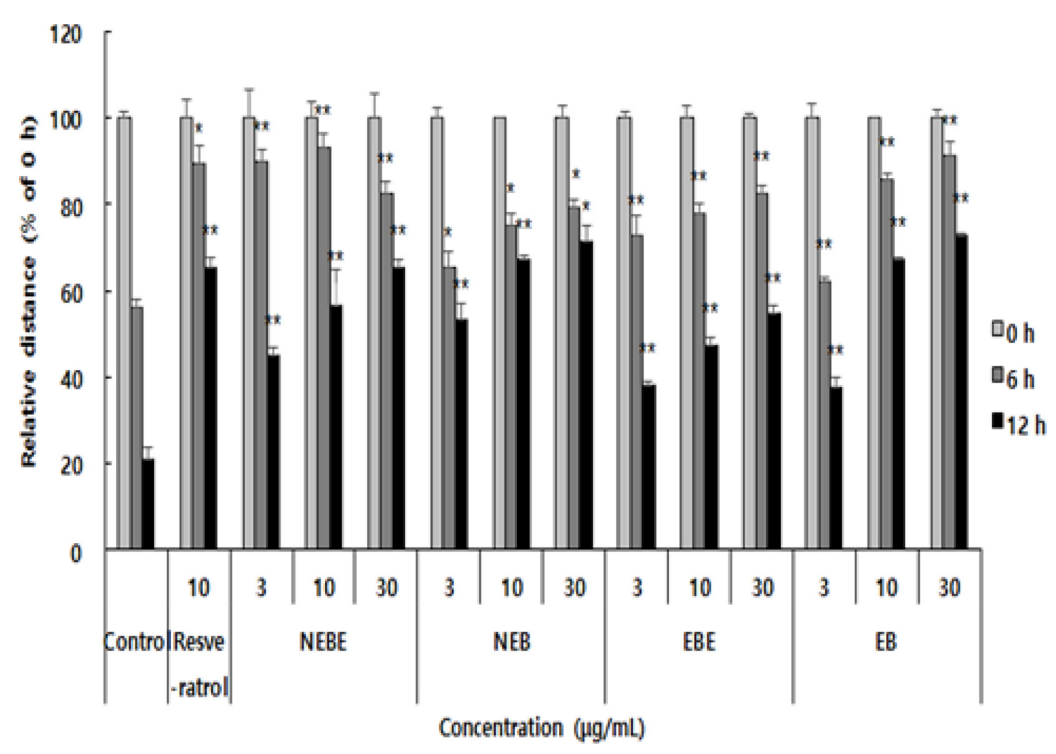

Fig. 5 Cancer cells (B16F10) migration inhibitory activity of Phellinus baumii with enzyme treatment by wound healing assay. NEBE, non-enzyme beta-glucan extract; NEB, non-enzyme beta-glucan; EBE, enzyme beta-glucan extract; EB, enzyme beta-glucan

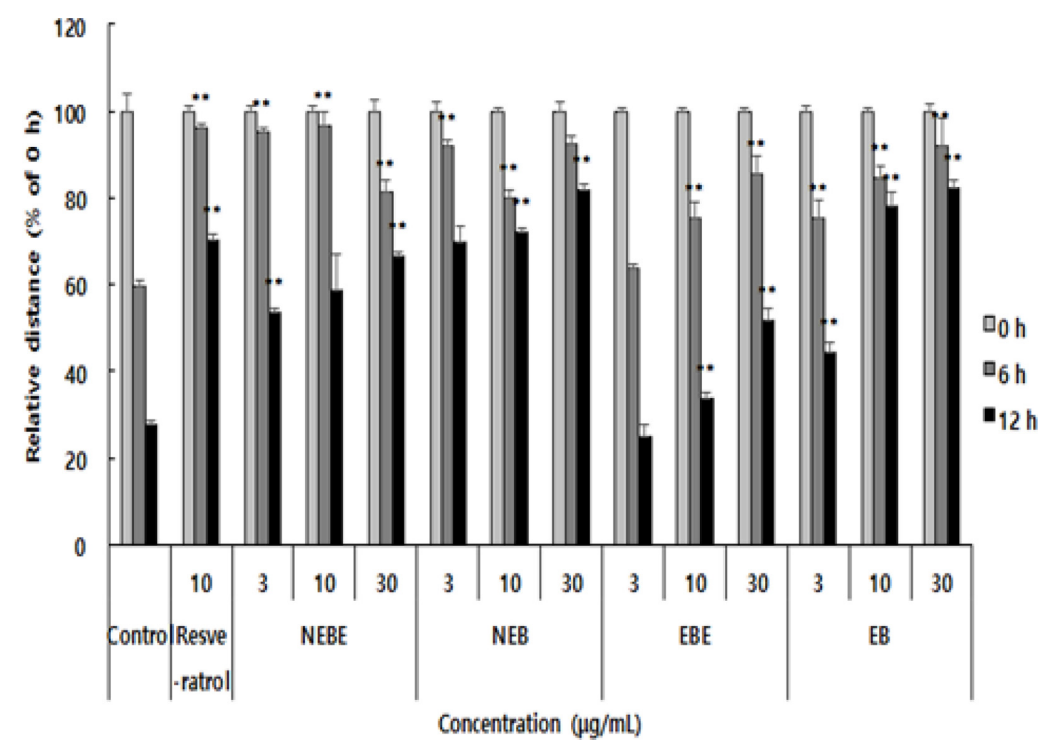

Fig. 6 Cancer cells (SK-MEL-5) migration inhibitory activity of Phellinus baumii with enzyme treatment by wound healing assay. NEBE, non-enzyme beta-glucan extract; NEB, non-enzyme beta-glucan; EBE, enzyme beta-glucan extract; EB, enzyme beta-glucan

모든 경우에서 음성 대조구에 비해 암세포 증식 억제 활성이 높게 나타났다. 대조구와 효소 전처리구 모두 정제 과정을 거 친 $\mathrm{NEB}, \mathrm{EB}$ 가 $\mathrm{NEBE}, \mathrm{EBE}$ 보다 높은 활성을 나타내었다. $\mathrm{B} 16 \mathrm{~F} 10$ 과 SK-MEL-5 모두에서 12시간 경과시 $\mathrm{EB} 30 \mu \mathrm{g} / \mathrm{mL}$ 를 처리한 경우 가장 높은 활성을 나타내었으며, 특히 양성 대 조구(resveratrol $10 \mu \mathrm{g} / \mathrm{mL}$ )에 비하여 높은 활성을 나타내었다. 팽이버섯 추출물 $1000 \mu \mathrm{g} / \mathrm{mL}$ 처리시 약 $70 \%$ 의 억제활성을 나 타냈다고 보고한 Lee 등(2009)의 결과와 비교 할 때, EB 30 $\mu \mathrm{g} / \mathrm{mL}$ 을 처리시 약 $70 \%$ 의 억제활성을 보여 더 낮은 농도에서 유사한 억제활성을 나타내었다.
감사의 글 본 결과물은 농림축산식품부의 재원으로 농림수산식품기술기획 평가원의 고부가가치식품기술개발사업의 지원을 받아 연구되었음(과제번호 314070-3).

\section{초 록}

본 연구에서는 국내산 상황버섯의 효소 가수분해 전처리를 통 한 $\beta$-glucan의 최적 추출조건을 확립하고 그에 따른 활성을 알 아보고자 추출 조건에 따른 생이화학적활성을 측정하였다. 효소 가수분해 조건을 최적화하기 위해 실시한 반응표면분석법의 결 
과 $0.66 \%(\mathrm{v} / \mathrm{v})$ 의 viscozyme 농도에서 6.08 시간 반응하는 것이 최적이라 예측되었으며 $\left(\mathrm{R}^{2}=0.9245\right)$, 이에 따라 최적 추출 조건 에서 추출한 시료의 $\beta$-glucan 함량은 $1.9594 \mathrm{~g} / 100 \mathrm{~g}$ 으로 측정 되었다. 추출 수율 $(0.76-16.40 \%)$ 은 $\mathrm{EBE}$ 가 $\mathrm{NEBE}$ 에 비해 약 3 배 높았다. $\beta$-glucan 순도(11.15-59.05\%)로 가장 높았으며, $\beta$ glucan 함량 또한 $0.26-3.38 \mathrm{~g} / 100 \mathrm{~g}$ 으로 $\mathrm{EB}(3.38 \mathrm{~g} / 100 \mathrm{~g})$ 가 가 장 높았다. 총당 함량 $(0.61-1.17 \mathrm{mg} / \mathrm{mL})$ 은 $\mathrm{NEB}, \mathrm{EB}$ 가 $\mathrm{NEBE}$, $\mathrm{EBE}$ 보다 높았으며, $\mathrm{EB}$ 가 가장 높았다. 구성당 분석 결과, 모든 추출물에서 glucose의 함량이 가장 높았으며, 대조구와 효소 전 처리구 모두 정제하면서 그 비율이 증가하였다. 단백질 함량 $(0.44-11.73 \mathrm{mg} / \mathrm{mL})$ 은 $\mathrm{NEBE}, \mathrm{EBE}$ 가 $\mathrm{NEB}, \mathrm{EB}$ 보다 높았으며, $\mathrm{EBE}$ 가 가장 높았다. FT-IR 분석 결과 $890 \mathrm{~cm}^{-1}$ 부근에서 peak 가 확인되었기에 $\beta$-glycosidic linkage를 가지고 있는 것으로 판 단하였다. MTT assay를 통해 B6F10과 SK-MEL-5 세포 독성 을 측정한 결과 $\mathrm{B} 6 \mathrm{~F} 10$ 의 경우 대조구의 세포 생존율을 $100 \%$ 로 하였을 때 세포 생존율이 $80 \%$ 이상으로 나타나 세포독성을 보이지 않았으나, SK-MEL-5에서는 $\mathrm{EBE}$ 를 $100 \mu \mathrm{g} / \mathrm{mL}$ 의 농도 로 처리하였을 때 세포 생존율이 $75 \%$ 로 나타나 약간의 세포독 성을 보였다. Wound healing assay를 통해 암세포 증식 억제 활성 측정 결과, 정제한 $\mathrm{NEB}, \mathrm{EB}$ 가 $\mathrm{NEBE}, \mathrm{EBE}$ 보다 활성이 높았으며, 특히 12시간일 때 $\mathrm{EB} 30 \mu \mathrm{g} / \mathrm{mL}$ 를 처리한 경우 B6F10과 SK-MEL-5 모두에서 가장 높은 활성을 나타내었다.

Keywords 베타글루칸 · 상황버섯 · 세포 독성 · 암세포 증식 억제 활성 · 효소 가수분해 전처리

\section{References}

Bae JS, Jang KH, Rhee MH, Jeong KS, Jo WS, Choi SG, Kim YH, Park SC (2003) Comparison on the Morphology, General Composition, Elemental Composition and Mineral Contents of Phellinus linteus, Phellinus baumii and Phellinus gilvus. Korean J Vet Res 43: 423-428

Cho JH, Lee JY, Lee MJ, Oh HN, Kang DH, Jhune CS (2013) Comparative Analysis of Useful $\beta$-glucan and Polyphenol in the Fruiting Bodies of Ganoderma spp. J Mushroom Sci Prod 11: 164-170

Chung HS, Youn KS (2005) Comparison of Pretreatment Methods for Extraction of Selected Components from Ganoderma lucidum. Korean J Food Preserv 12: 130-134

Dubois M, Gilles KA, Hamitton JK, Rebers PA, Smith F (1956) Colorimetric Method for Determination of Sugars and Related Substances. Anal Chem 28: 350-356

Heo JC, Park JY, Lee JM, Kwon TK, Kim SU, Chung SK, Lee SH (2005) Wisteria Floribunda Gall Extract Inhibits Cell Migration in Mouse B16F10 Melanoma cells by Regulating CD44 Expression and GTPRhoA Activity. J Ethonopharmacol 102: 10-14

Kim AR, Kim JE, Park SN (2011) Antioxidative Activity and Component Analysis of Phellinus linteus Extracts. Korean J Soc Cosmet 37: 309_
318

Kim DY, Teng H, Choi YH (2012) Optimization of Ultrasonic-assisted Extraction Process for Inonotus obliquus Using Response Surface Methodology. Current Research on Agriculture and Life Sciences 30: 68-75

Kim JH, Lee SC, Ju YC (2007) Effect of Far-infrared Irradiation on the Antioxidant Activity of Extracts from Phellinus igniarius and Ganoderma lucidum. Korean J Food Sci Technol 39: 386-389

Kwon JH, Jacqueline M. R., Belanger, J.R. Jocelyn Pare (2003) Optimization of Microwave-Assisted Extraction (MAP) for Ginseng Components by Response Surface Methodology. J Agric Food Chem 51: 1807-1810

Lee JS, Lee SH, Jang YM, Lee JD, Lee BH, Jung JY (2011) Macrophage and Anticancer of Feed Additives on $\beta$-Glucan from Schizophyllum commune in Breast Cancer Cells. J Korean Soc Food Sci Nutr 40: 949955

Lee PH, Park SY, Jang TH, Yim SH, Nam SH, In MJ, Kim DC, Chae HJ (2014) Effects of Complex Carbohydrase Treatment on Physiological Activities of Pear Peel and Core. J Korean Soc Food Sci Nutr 43: 404410

Lee SR, Nam DY, Lee HJ, Park CH, Heo JC, Kim JG, Lee JM, Lee CY, Park HJ, Lee SH (2009) Analysis of Anti-Tumor Activity of Flammulina velutipes Extract on B16 cells. Korean J Food Preserv 16: 599-603

Maja K, Anita K, Miomir N, Dragica J, Johannes P.F.G. H, Leo J.L.D. Van G (2011) Antioxidative and immunomodulating activities of polysaccharide extracts of the medicinal mushrooms Agaricus bisporus, Agaricus brasiliensis, Ganoderma lucidum and Phellinus linteus. Food Chem 129: 1667-1675

Mossmann T (1983) Rapid colorimetric assay for cellular growth and survival: application to proliferation and cytotoxicity assays. J Immunol Methods 65: 55-63

Park CH, Heo JC, Nam DY, Lee SR, Nam SH, Son MS, Hwang YH, Lee SH (2009) Comparison of immuno-suppressive activities of Pintol isolated from soybean. Korean J Food Preserv 16: 449-453

Park MK, Kim CH (2008) Effect of Pre-heating Conditions on Extraction Yield of Phelinus linteus Tea. J Korean Soc Food Sci Nutr 37: 653-659

Rhee YK, Han MJ, Park SY, Kim DH (2000) In vitro and in vivo Antitumor Activity of the Fruit Body of Phellinus linteus. Korean J Food Sci Technol 32: 477-480

Shiao MS, Lee KR, Lin JJ, Wang CT (1994) Phytochemicals for Cancer Prevention II, Teas, Spices and Herbs. American Chemical Society, Washington DC

Shin YK, Jang HS, Kim JS, Ryu HY, Kim JK, Kwun IS, Sohn HY (2008) Solid Fermentation of Medicinal Herb Using Phellinus baumii Mycelium and Anti-thrombin and Antioxidation Activlity of its Methanol Extract. Kor J Microbiol Biotechnol 36: 201-208

Smith PK, Krohn RI, Hermanson GT, Mallia AK, Gartner FH, Frovenzano MD, Fujimoto EK, Goeke NM, Olson BJ, Klenk DC (1985) Measurement of protein using Bicinchoninic acid. Anal Chem 150: 7985

Suh HJ, Noh DO, Choi YM (2002) Solubilization of onion woth polysaccharide-degrading enzymes. Int J Food Sci Technol 37: 65-71

Vlasta M, Romano B, Gerwin P (2001) Vibrational Spectroscopic Characterization of wild growing mushrooms and toadstools. Spectrochimica Acta Part A 57: 2815-2829 